\title{
Predictive equations for early-life indicators of future body weight in Holstein dairy heifers
}

\author{
Tabitha S. Hurst, ${ }^{1}$ Nicolas Lopez-Villalobos, ${ }^{2}$ and Jacquelyn P. Boerman ${ }^{1 *}$ \\ ${ }^{1}$ Department of Animal Sciences, Purdue University, West Lafayette, IN 47907 \\ ${ }^{2}$ School of Agriculture and Environment, Massey University, Palmerston North 4442, New Zealand
}

\begin{abstract}
It takes an approximate 2 -yr investment to raise a replacement heifer from birth to first calving, and selecting the most productive heifers earlier in life could reduce input costs. Daily milk consumption, serum total protein, pneumonia and scours incidences, body size composite, birth weights, and incremental body weights were collected on a commercial dairy farm from October 1, 2015, to January 1, 2019. Holstein calves (n $=5,180)$ were fed whole pasteurized nonsalable milk with a 30\% protein and 5\% fat enhancer added at 20 $\mathrm{g} / \mathrm{L}$ of milk through an automated calf feeding system (feeders $=8$ ) for $60 \mathrm{~d}$ on average. Calves were weighed at birth and several other times before calving. Average birth weight of calves was $40.6 \pm 4.9 \mathrm{~kg}$ (mean \pm standard deviation), serum total protein was $6.7 \pm 0.63$ $\mathrm{mg} / \mathrm{dL}$, and cumulative 60-d milk consumption was $508.1 \pm 67.3 \mathrm{~L}$ with a range of 179.9 to $785.1 \mathrm{~L}$. Daily body weights were predicted for individual animals using a third-order orthogonal polynomial to model body weight curves. The linear and quadratic effects of cumulative 60-d milk consumption, birth weight, feeder, year born, season born, respiratory incidence, scours incidence, and body size composite score were significant when predicting heifer body weight at $400 \mathrm{~d}$ $\left(\mathrm{pBW}_{400}\right)$ of age. There was up to a 263-kg difference in $\mathrm{pBW}_{400}$ between the heaviest and lightest animal. Birth weight had a significant effect on predicted weights up to $400 \mathrm{~d}$, and for every 1-kg increase in birth weight, there was a $2.5-\mathrm{kg}$ increase in $\mathrm{pBW}_{400}$. Quadratic effect of cumulative 60-d milk consumption was significant up to $400 \mathrm{~d}$. We divided 60-d milk consumption into quartiles, and heifers had the highest $\mathrm{pBW}_{400}$ in the third quartile when $60-\mathrm{d}$ consumption was between 507.8 and 552.5 L. Body size composite score showed a $21.5-\mathrm{kg}$ difference in $\mathrm{pBW}_{400}$ between the top and bottom 25 th percentile of heifers. Heifers were $4.2 \mathrm{~kg}$ lighter at 400
\end{abstract}

Received March 19, 2020.

Accepted August 28, 2020.

*Corresponding author: jboerma@purdue.edu $\mathrm{d}$ if treated for respiratory disease $3+$ times during the first $60 \mathrm{~d}$ of life compared with heifers not treated for respiratory disease. Measurements that can be obtained in the early life of dairy calves continue to influence heifer growth up to $400 \mathrm{~d}$ of age.

Key words: growth, autofeeder, dairy calf

\section{INTRODUCTION}

Raising high quality dairy replacement heifers is important to ensure high productivity and longevity of dairy farms. An approximate 2-yr investment is incurred before replacement heifers have the potential to generate income. Reported cost for raising a replacement heifer is $\$ 2,510 /$ heifer from birth to first parturition (Akins and Hagedorn, 2015). Due to the immense input costs, selecting the most efficient replacement heifers for the herd is more important than ever. Increasing growth rate of heifers early in life may result in earlier age at first calving, increased lifetime milk production (Raeth-Knight et al., 2009; Soberon et al., 2012), and reduction in overall raising costs (Tozer and Heinrichs, 2001; Ettema and Santos, 2004). Understanding what variables affect BW could help producers better select replacement heifers for their herd. Early-life factors that influence growth include proper colostrum management (Renaud et al., 2018), accelerated feeding programs (Davis Rincker et al., 2011), health incidences (Stanton et al., 2012), different housing systems (Costa et al., 2014), and different environmental conditions (ChesterJones et al., 2017). Many management strategies have focused on obtaining a growth advantage during the preweaning phase.

One strategy to influence heifer growth is to feed calves with an accelerated feeding program. A conventional calf feeding program offers calves milk or milk replacer at $10 \%$ of BW (Jasper and Weary, 2002; Khan et al., 2007; Drackley, 2008). In contrast, an accelerated feeding program allows the calf to consume increased amounts of milk or milk replacer during the preweaning phase, and often these programs increase the concentration of protein offered in the milk replacer (up to 
$30 \%$ CP; Khan et al., 2011). Another way to offer an accelerated feeding program is to increase the volume of milk supplied to calves. Khan et al. (2011) identified that calves can consume up to $20 \%$ of their BW in milk or milk replacer, which doubles the amount of milk offered in the conventional feeding systems. An extensive number of publications have reported the effect these 2 feeding programs have on the growth of heifers without a consensus on the long-term benefits of the heifer's life.

Accelerated feeding programs report increases in growth at weaning (Miller-Cushon et al., 2013; Rosenberger et al., 2017; Byrne et al., 2018). Calves fed increased milk replacer solids with an increased nutrient density milk replacer program calved $27.5 \mathrm{~d}$ sooner than calves fed on a conventional feeding program (Raeth-Knight et al., 2009). Soberon et al. (2012) reported the growth of calves during the preweaning phase was highly correlated with first lactation milk production and reported that for every 1-kg increase in ADG during the preweaning phase, first lactation milk production increased by $850 \mathrm{~kg}$. Additionally, other research has shown positive behavioral effects when offering calves an accelerated amount of milk (von Keyserlingk et al., 2009; de Passillé et al., 2011). However, a concern with feeding calves an accelerated amount of milk is the increased cost associated with these programs. Quigley et al. (2006) reported a $\$ 27.22$ difference in milk replacer cost per animal when feeding a conventional milk replacer fed at $454 \mathrm{~g} / \mathrm{d}(20 \%$ $\mathrm{CP}, 20 \%$ fat) versus an accelerated milk replacer fed at varying rates with a maximum of $908 \mathrm{~g} / \mathrm{d}$ from d 15 to 31 (28\% CP, $16 \%$ fat).

One way to implement the accelerated feeding strategy is to use automatic calf feeders. With the increased acceptance of technology in agriculture industries (Rutten et al., 2013), the use of automatic calf feeders has increased without fully understanding how to best use the data generated or how to alter management for calves. Variation in individual milk consumption from automatic calf feeders can provide information on health status of animals. Respiratory disease is a leading cause of morbidity in preweaned dairy calves. Rates of respiratory disease vary from farm to farm, and Heins et al. (2014) reported a $61 \%$ treatment rate for respiratory disease (range 20.7-89.9\% treatment) on 4 different farms. Calves identified with respiratory disease have been shown to have reduced growth rate (Cramer and Ollivett, 2019), increased age at first calving (Teixeira et al., 2017), and lower total milk production (527.3 kg; Dunn et al., 2018) during first lactation.

Understanding which variables collected during the preweaning phase influences future outcomes of heif- ers, which may allow farms the ability to make more informed management decisions regarding youngstock. However, data collected on farms is not well integrated and makes the use of data time consuming for farmers. Therefore, the objective of this study was to investigate if variables collected during the preweaning phase can be used to predict future BW of replacement heifers, and to use the predicted BW to help identify the most profitable heifers to return to the milking herd. We hypothesized that milk consumption and incidences of respiratory disease that occur preweaning will influence BW of dairy heifers up to $400 \mathrm{~d}$ of age.

\section{MATERIALS AND METHODS}

\section{Protocols Followed by Farm}

All calves were housed at a commercial dairy farm in north-central Indiana. At birth, calves were fed 3.8 $\mathrm{L}$ of colostrum via an esophageal feeder; $6 \mathrm{~h}$ following the first colostrum feeding, they received another $1.9 \mathrm{~L}$ before being introduced to an automated calf feeder on d 1. To measure success of passive transfer of immunity, blood was drawn from the jugular vein of calves between 1 and $10 \mathrm{~d}$ of age, and serum total protein values (STP) were measured using a refractometer. The farm determined success of passive transfer if calves had a STP value $\geq 6.0 \mathrm{~g} / \mathrm{dL}$, and $95 \%$ of calves had a STP of $6.0 \mathrm{~g} / \mathrm{dL}$ or greater.

Calves were fed with 8 automated calf feeders (Förster-Technik, Engen, Germany) located in 4 calf barns. Each barn contained 4 pens with 2 feeding stations per pen, and each feeder supplied milk to 2 pens. Each pen was $9.14 \times 24.38 \mathrm{~m}$ in size and contained approximately 50 to 60 calves.

All calves were allocated up to $24 \mathrm{~L}$ of milk per day from d 0 to 32 . The automated calf feeding system only offered a set amount of milk every $2 \mathrm{~h}$, and this amount incrementally increased as the calf got older. Each calf was allocated $2 \mathrm{~L}$ of milk every $2 \mathrm{~h}$ until d 10. From d 10 to 21 calves could consume $2.5 \mathrm{~L}$ every $2 \mathrm{~h}$. Then, calves could drink up to $3 \mathrm{~L}$ every $2 \mathrm{~h}$ until d 32 . At d 32 , the milk step-down phase began and the maximum milk allowance incrementally dropped by $2 \mathrm{~L} / \mathrm{d}$ until d 39, when calves had a maximum milk allotment of $10 \mathrm{~L} / \mathrm{d}$. From d 39 to d 46, calves were offered up to $10 \mathrm{~L} / \mathrm{d}$, and milk allotment decreased to $8 \mathrm{~L} / \mathrm{d}$ at d 46. Milk allotment then continued to be reduced until calves were fully weaned at $60 \pm 4.6 \mathrm{~d}$ of age (mean $\pm \mathrm{SD}$ ). Refer to Supplemental Figure S1 (https://doi .org/10.3168/jds.2020-18560) for the exact step-down procedure. Additionally, the average milk consumption can be seen in Supplemental Figure S2 (https://doi 
.org/10.3168/jds.2020-18560). Calves were fed whole pasteurized nonsalable milk with a $30 \%$ protein and $5 \%$ fat enhancer added at $20 \mathrm{~g} / \mathrm{L}$ of milk. Adding balancers to whole or nonsalable milk has been shown to increase gain, BW, and feed efficiency of preweaned dairy calves in comparison to feeding only waste milk and is a way to increase the nutrient content fed to calves without increasing the volume of milk fed (James and Scott, 2005). The farm uses a balancer to have the ability to feed their waste milk even when they have a fluctuating amount of nonsalable milk available.

Training calves to drink from the automated calf feeder was done 2 times per day by guiding and familiarizing calves to the feeding stations. Calves who did not drink at least $4 \mathrm{~L}$ from d 1 to 14 ( $83 \%$ of calves drank $\geq 4 \mathrm{~L} / \mathrm{d}$ by d 14), or at least $5 \mathrm{~L}$ from 15 to 30 d ( $81 \%$ of calves drank $\geq 5 \mathrm{~L} / \mathrm{d}$ by d 30 ) were identified and manually fed. Calves were offered ad libitum starter (18\% CP and $3.5 \%$ fat) and water from d 1 of age inside the autofeeder pens.

Barns were ventilated with 2 positive pressure ventilation tubes and run year-round. When the temperature increased above $15.6^{\circ} \mathrm{C}$, all of the curtains were open. Below $15.6^{\circ} \mathrm{C}$, curtains and side doors were incrementally closed until the temperature reached $-6.7^{\circ} \mathrm{C}$ or below, when all curtains were closed. Weather was monitored morning and evening, and adjusted depending on the temperature.

Calves were diagnosed with bovine respiratory disease if they had a drinking speed deviation of $80 \%$ compared with the previous day, elevated temperature $\left(\geq 39.5^{\circ} \mathrm{C}\right)$, and rapid breathing compared with pen mates. If all symptoms were present, calves were treated with subcutaneous thulathromycin (DRAXXIN, Zoetis, Kalamazoo, MI) or intravenous flunixin meglumine (Intervet Inc., Roseland, NJ). After d 4 of treatment, calves were reevaluated, and if no improvement was observed, they were retreated with florfenicol and flunixin meglumine (RESFLOR GOLD, Intervet Inc.) subcutaneously. After $\mathrm{d} 7$ of the first treatment, calves were retreated with tulathromycin and flunixin meglumine if symptoms did not resolve themselves. Calves were treated for scours if they had a drinking speed deviation of $80 \%$ compared with the previous day, loose stools, and appeared dehydrated or depressed. Calves that had a lower drinking speed deviation and loose stool were given Bismuth Subsalicylate (Durvet Inc., Blue Springs MO). Calves that appeared dehydrated or depressed were also given oral electrolytes in addition to Bismuth Subsalicylate. Calves that had blood in the stool where treated with Megalumine (Intervet Inc.); however, only those treated with antibiotics were recorded in DairyComp 305 (VAS, Tulare, CA).
Daily milk consumption for calves was collected through Förster-Technik automated calf feeders from October 1, 2015, to January 1, 2019. Total and 60-d milk consumption was calculated by individual data collected from the automated calf feeders. The value varied from the total days on feeder because calves were kept in the autofeeder longer than they were offered milk. The time in the feeder varied depending on calving frequency of the farm. Each calf was designated to 1 feeder, and this factor was included in the model. To account for the variation in day on the autofeeder, we added this variable into the analysis. We used 60-d milk consumption to standardize milk consumption and compare the amount of milk consumed on the average age of weaning.

Health incidences, STP values, BW, and birthdates were obtained from DairyComp 305. When deciding how to eliminate inaccurate farm collected STP, it was found that Elsohaby et al. (2015) used calves 1 to $11 \mathrm{~d}$ of age for a project examining failure of passive transfer of immunity. Wilm et al. (2018) found that STP values in calves taken up to $9 \mathrm{~d}$ old are highly correlated with each other $(r \geq 0.88)$, and values taken up to 10 $\mathrm{d}$ old $(\mathrm{r}=0.76)$ can be positively correlated to one another. Higher STP values can be an indication of calf dehydration (Tyler et al., 1996); therefore, we did not use STP values collected after $10 \mathrm{~d}$ old or if STP was higher than $10 \mathrm{~g} / \mathrm{dL}(\mathrm{n}=26$ for age $>10 \mathrm{~d}$, and $\mathrm{n}=$ 5 for STP $>10 \mathrm{~g} / \mathrm{dL}$ ). Birth dates were extracted from DairyComp 305, and 4 birth seasons were defined as follows: winter (January-March), spring (April-June), summer (July-September), and fall (October-December). Average temperature for each season can be viewed in Supplemental Table S1 (https://doi.org/10 $.3168 /$ jds.2020-18560). Year of birth was determined from the birth date. Incremental weights were collected on farm at birth ( $0 \mathrm{~d}$ of age), leaving the autofeeder, approximately 3 mo of age, and breeding using an individual weigh scale (Tru-Test Limited, Auckland, New Zealand). Health events were obtained via DairyComp 305. Calf respiratory disease and scours were obtained from DairyComp 305, and an individual event was defined as antibiotic treatment given $5 \mathrm{~d}$ apart from each other.

Postweaning, calves were moved to transition pens on the dairy until they reach 4 to 6 mo old. Following the transition pens, calves were moved off farm to 3 different heifer raising facilities. As calves were moved to transition pens, they stayed within the same cohort of animals from the automatic calf feeder. Heifers received a transition diet that contained ground alfalfa hay, and they were offered additional forage approximately 1 mo after transitioning. 


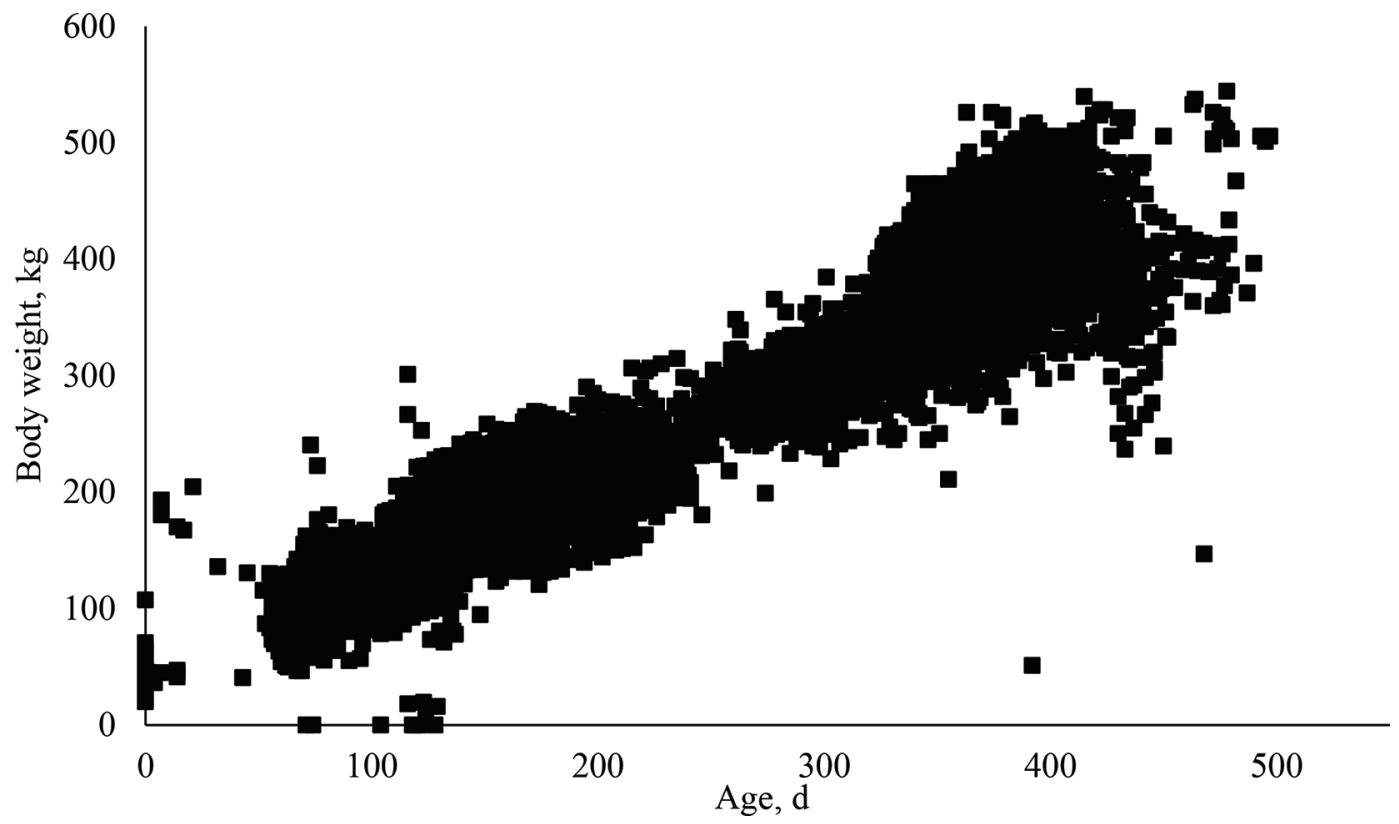

Figure 1. Initial, raw heifer BW data before predicted BW analysis was performed and outliers were removed. Body weights were collected from October 1, 2015, to January 1, 2019.

\section{Animal Data}

A total of 9,099 calves with automated milk feeder consumption were included in the analysis. Calf milk consumption, birth date, number of days on feeder, season born, year born, respiratory incidence, and scours incidence files were combined; all calves had to have milk consumption and birthdate to be retained. Of the 9,099 calves, birth date was recorded for 8,764 calves. From this data set, calf weights (Figure 1) and body size composite values were added, and animals had to have at least 1 weight to be included. Body size composite score was collected through the Zoetis Clarifide program, which estimates an individual animal's expected differences in overall mature size and compacity by combining estimates of stature, strength, body depth, and width of rump and distributes the data into a single composite index (Zoetis). After merging these files, there were 7,792 calves in the data set. Daily BW were predicted for each animal using orthogonal polynomials (explained with more details below). Outliers were identified from predicted BW at each of the 8 time points, and individual weights were removed if the weight for that time point was above or below 4 standard deviations from the mean $(\mathrm{n}=45)$, similar to outlier removal in Pietersma et al. (2006). Similarly, 7 birth weights were removed using the same outlier removal process for the predicted BW. After the predicted BW were calculated for each day of age, 6,212 animals remained in the data set. Lastly, STP values were added to the data set, and the final analysis data set included 60-d milk consumption, feeder number, number of day on feeder, year born, season born, respiratory incidence, scours incidence, body size composite, and STP values from 5,180 animals. Number of animals included at each step of merging and number of animals included in the final 400-d predicted BW model after all insignificant values were excluded are displayed (Table 1). Respiratory treatment rate was categorized into 4 incidence rates: $0=$ animals were not treated for respiratory, $1=$ animals were treated once, $2=$ animals were treated twice, and $3=$ animals were treated 3 or more times for respiratory disease during the first $60 \mathrm{~d}$ of life.

\section{Body Weight Model Calculation}

Calves were not weighed on the same day of life; therefore, individual regressions were used to generate daily BW. Body weight curves for the population and each animal were modeled with a random regression model based on a third-order Legendre polynomial (Kirkpatrick et al., 1990) using the MIXED procedure of SAS version 9.4 (SAS Institute Inc., Cary, NC). The model was represented as:

$$
\begin{aligned}
& \mathrm{w}_{\mathrm{it}}=\left(\beta_{0} \mathrm{p}_{0 \mathrm{t}}+\beta_{1} \mathrm{p}_{1 \mathrm{t}}+\beta_{2} \mathrm{p}_{2 \mathrm{t}}+\beta_{3} \mathrm{p}_{3 \mathrm{t}}\right) \\
& +\left(\alpha_{0_{\mathrm{i}}} \mathrm{p}_{0 \mathrm{t}}+\alpha_{1_{\mathrm{i}}} \mathrm{p}_{1 \mathrm{t}}+\alpha_{2_{\mathrm{i}}} \mathrm{p}_{2 \mathrm{t}}+\alpha_{3_{\mathrm{i}}} \mathrm{p}_{3 \mathrm{t}}\right)+\mathrm{e}_{\mathrm{it}},
\end{aligned}
$$


Table 1. Data organization and number of animals included in analysis

\begin{tabular}{ll}
\hline Data cleaning $^{1}$ & Number of animals \\
\hline Autofeeder milk consumption & 9,099 \\
Data set 1 (milk consumption, birthdate, respiratory, and scours) & 8,764 \\
Data set 2 (data set 1, feeder number, actual animal weights, genetic body size composite score, birth weight) & 7,792 \\
Data set 3 (data set 2, predicted BW) & 6,212 \\
Data set 4 (data set 3 with 45 outlying weights removed) & 6,206 \\
Data set 5 (data set 3, with STP ${ }^{3}$ ) & 6,206 \\
Predicted BW model at $400 \mathrm{~d}$ & 5,180 \\
\hline${ }^{1}$ All animals included in the final analysis were required to have all variables in the model. Analysis started with 9,099 animals and ended with \\
5,180 heifers.
\end{tabular}

where $\mathrm{w}_{\mathrm{it}}$ is the weight of the ith animal at day $\mathrm{t}, \beta_{\mathrm{k}}$ is the kth fixed regression coefficient for the population, and $\alpha_{k_{i}}$ is the kth random regression coefficient for animal $\mathrm{i} ; \mathrm{p}_{\mathrm{kt}}$ are the functions normalized to $\mathrm{x}$, which is the standardized unit of time defined as $\mathrm{x}=2\left(\frac{\mathrm{t}-\mathrm{t}_{\min }}{\mathrm{t}_{\max }-\mathrm{t}_{\min }}\right)-1$, calculated as:

$$
\begin{aligned}
& \mathrm{p}_{0}(\mathrm{t})=1, \quad \mathrm{p}_{1}(\mathrm{t})=\mathrm{x}, \quad \mathrm{p}_{2}(\mathrm{t})=\frac{1}{2}\left(3 \mathrm{x}^{2}-1\right), \text { and } \\
& \mathrm{p}_{3}(\mathrm{t})=\frac{1}{2}\left(5 \mathrm{x}^{3}-3 \mathrm{x}\right) .
\end{aligned}
$$

In the current study, $t_{\min }=1 \mathrm{~d}$ and $t_{\max }=400 \mathrm{~d}$ so that the weight records between 1 to $400 \mathrm{~d}$ were converted into the interval of -1 to 1 . The random error is represented by $\mathrm{e}_{\mathrm{it}}$. The third-order orthogonal polynomial was determined as the best fit based on Bayesian information criterion compared with second and fourth order orthogonal polynomial. Other measures of goodness of fit were $\mathrm{R}^{2}$ and relative prediction error (RPE). The RPE was calculated as follows:

$$
\mathrm{RPE}=\left(\frac{\sqrt{\mathrm{MSPE}}}{\overline{\mathrm{A}}}\right) \times 100,
$$

where MSPE is the mean square prediction error. The MSPE was calculated as follows:

$$
\operatorname{MSPE}=\sum_{\mathrm{i}=1}^{\mathrm{N}}\left(\mathrm{A}_{\mathrm{i}}-\mathrm{P}_{\mathrm{i}}\right)^{2} / \mathrm{N}
$$

where $A_{i}$ is the actual weight, $P$ is the predicted weight, $\overline{\mathrm{A}}$ is the mean of the actual weights, $\mathrm{N}$ is the number of records, $\mathrm{i}=1,2, \ldots \mathrm{N}$.

Body weight was only predicted up to $400 \mathrm{~d}$ because of the limited number of BW collected between 500 and
$600 \mathrm{~d}$ and the increased variability of weights around calving due to differences in fetus size and mammary development. Therefore, weights could not be accurately predicted after $400 \mathrm{~d}$ with this data set, and thus the effect of early life on heifer BW was studied up to $400 \mathrm{~d}$ of age. Certain time points $(1,60,100,150,200$, 300,365 , and $400 \mathrm{~d}$ ) were used for analysis.

\section{Statistical Analysis}

Data were analyzed using SAS 9.4. The effect of 9 factors on BW at the different ages of the animals were evaluated with a linear model using the MIXED procedure. Variables included in the model were the linear and quadratic effects of milk consumption, feeder, number of days in the feeder, year born, season born, respiratory disease score, birth weight, STP, and body size composite score. Only factors with significant effects $(P<0.05)$ were retained in the final model for weight for each age. Body weight curves were modeled for different scenarios of factors affecting weights at different ages to illustrate the effect of these factors on the long-term weight of growing heifers. Average daily gain was calculated at each of the selected heifer ages with a cubic polynomial.

\section{RESULTS}

Estimates of the regression coefficients that describe the BW curve of the population are presented in Table 2. Measures of goodness of fit of the random regression model were $\mathrm{R}^{2}=0.9956$ and $\mathrm{RPE}$ of $4.36 \%$. Results of ANOVA of predicted weights at different ages are presented in Table 3, showing the number of variables included in the model along with the number of animals and the model's corresponding $\mathrm{R}^{2}$ values. The final model that explained variation on predicted weight at $400 \mathrm{~d}\left(\mathbf{p B W}_{400}\right)$ included the linear and quadratic effects of 60-d milk consumption, birth weight, feeder, year born, season born, respiratory incidence, scours in- 
cidence, and body size composite score (all $P<0.0001$; Table 4). The number of days on feeder and STP value were not significant in the model $(P \geq 0.20)$, and thus removed. The final equation for $\mathrm{pBW}_{400}$ was

$$
\begin{gathered}
\mathrm{pBW}_{400}(\mathrm{~kg})=197.37+0.48 \\
\times(\text { milk consumption in } \mathrm{L})-0.0003 \\
\times(\text { milk consumption in } \mathrm{L})^{2}+1.60 \\
\times(\text { birth weight in } \mathrm{kg})+\text { feeder }+ \text { year born } \\
+ \text { season born }+ \text { respiratory incidence } \\
+ \text { scours incidence }+8.89 \\
\times \text { (body size composite score }) .
\end{gathered}
$$

Feeder number had a significant effect on $\mathrm{pBW}_{400}$. Between the 8 feeders, there was up to a $17-\mathrm{kg}$ difference in $\mathrm{pBW}_{400}$. The $\mathrm{pBW}_{400}$ of heifers was highest in 2015 and significantly decreased every year, with calves in 2019 having the lowest $\mathrm{pBW}_{400}$. Calves born in the spring had the highest $\mathrm{pBW}_{400}$. Calves born in the fall had the lowest $\mathrm{pBW}_{400}$.

Even though feeder, season the calf was born in, and the year the calf was born in significantly affected the BW of heifers up to $400 \mathrm{~d}$ of age, they were excluded from the final model because they were random factors that cannot be replicated; therefore, they would not be able to be determined for a predictive equation, which was similar to reports from (Cue et al., 2012). Our objective was to use the significant variables from early life to generate a predictive model that farms could use to select dairy replacement heifers at an earlier age. Therefore, significant and controllable variables were the linear and quadratic effects of milk consumption, birth weight, respiratory incidence, scours incidence, and body size composite score (all $P<0.0001$; Table $5)$. The predictive equation without random effects was:

$$
\begin{gathered}
\mathrm{pBW}_{400}(\mathrm{~kg})=193.14+0.55 \\
\times(\text { milk consumption in } \mathrm{L})-0.0004 \\
\times(\text { milk consumption in } \mathrm{L})^{2}+1.66 \\
\times(\text { birth weight in } \mathrm{kg})+\text { respiratory incidence } \\
\quad+\text { scours incidence }+8.53 \\
\times(\text { body size composite score }) .
\end{gathered}
$$

Predicted BW of 5 individual heifers with different values for milk consumption, season born, respiratory disease, body size composite score, birth weight, and STP is displayed in Figure 2. A 210-kg difference in $\mathrm{pBW}_{400}$ exists between heifers $\mathrm{E}$ and $\mathrm{C}$ (Figure 2). The animals
Table 2. Estimates of regression coefficients for the third-order orthogonal polynomial of the growth curve of dairy heifers in an accelerated feeding program fed to preweaned dairy calves

\begin{tabular}{lcc}
\hline Coefficient & Estimate & SE \\
\hline$\beta_{0}$ & 232.27 & 0.3152 \\
$\beta_{1}$ & 187.90 & 0.3331 \\
$\beta_{2}$ & -3.32 & 0.3077 \\
$\beta_{3}$ & 0.8703 & 0.2706 \\
\hline
\end{tabular}

in Figure 2 had large variation in the significant variables from the model: milk consumption, birth weight, body size composite score, and respiratory differences. For example, heifer C drank 203.6 L less milk, had a higher birth weight, was treated for respiratory disease, and had a higher body size composite score than heifer E. The differences in inputs between these 2 heifers is observed by differences in $\mathrm{pBW}_{400}$. The significant early-life predictive variables account for $31 \%$ of the variation in BW at $400 \mathrm{~d}$; therefore, other variables contribute to the difference seen at $400 \mathrm{~d}$ as well.

The ADG at different ages are shown in Figure 3. The ADG was reduced from $1.00 \mathrm{~kg} / \mathrm{d}$ at $60 \mathrm{~d}$ to 0.91 at $400 \mathrm{~d}$ of age. Average milk consumption by animal on this farm was $508.1 \pm 67.3 \mathrm{~L}$ (mean $\pm \mathrm{SD}$ ), which averaged $8.5 \mathrm{~L} / \mathrm{d}$ with a range from 179.9 to $785.1 \mathrm{~L}$

Table 3. Organization of predicted BW analysis by age of animals; table displays number of contributing variables in the model, number of animals in the model, and the $\mathrm{R}^{2}$ associated with each model at each age

\begin{tabular}{lccc}
\hline Age $(\mathrm{d})$ & $\begin{array}{c}\text { Number of } \\
\text { contributing } \\
\text { variables }\end{array}$ & $\begin{array}{c}\text { Number of } \\
\text { animals } \\
\text { in model }\end{array}$ & $\mathrm{R}^{2}$ \\
\hline 60 & $9^{1}$ & 5,001 & 0.58 \\
100 & $9^{1}$ & 5,003 & 0.58 \\
150 & $8^{2}$ & 5,189 & 0.52 \\
200 & $8^{2}$ & 5,188 & 0.44 \\
300 & $8^{2}$ & 5,189 & 0.33 \\
365 & $7^{3}$ & 5,188 & 0.31 \\
400 & $7^{3}$ & 5,180 & 0.31 \\
Predictive (400) & $4^{4}$ & 5,180 & 0.27 \\
\hline
\end{tabular}

${ }^{1}$ Variables included in the model: milk consumption, feeder $(\%$ of animals: $1=15.1 \%, 2=14.4 \%, 3=14.3 \%, 4=14.3 \%, 5=4.0 \%, 6=$ $8.2 \%, 7=14.9 \%, 8=14.8$ ), number of days in the feeder, year born (\% of animals: $2015=0.1 \%, 2016=18.1 \%, 2017=46.1 .0 \%, 2018=$ $35 \%, 2019=0.7 \%)$, season born (\% of animals: winter $=23.3 \%$, spring $=20.7 \%$, summer $=26.3 \%$, fall $=29.8 \%)$, respiratory disease $(\%$ of animals in each category $0=45.1 \%, 1=35.3 \%, 2=14.4 \%, 3=5.2 \%$ ), birth weight, serum total protein, body size composite score.

${ }^{2}$ Variables included in the model: milk consumption, feeder, number of days in the feeder, year born, season born, respiratory disease, birth weight, body size composite score.

${ }^{3}$ Variables included in the model: milk consumption, feeder, year born, season born, respiratory disease, birth weight, body size composite score.

${ }^{4}$ Variables included in the model: milk consumption, respiratory disease, birth weight, body size composite score. 
Table 4. Parameter estimates of significant variables in the model used to predict BW at $400 \mathrm{~d}$ old

\begin{tabular}{|c|c|c|c|}
\hline Variable & Estimate & $\mathrm{SE}$ & $P$-value \\
\hline Intercept & 197.37 & 19.65 & $<0.0001$ \\
\hline Milk consumption & 0.48 & 0.06 & $<0.0001$ \\
\hline Milk consumption $\times$ milk consumption & -0.0003 & 0.000057 & $<0.0001$ \\
\hline Birth weight & 1.60 & 0.09 & $<0.0001$ \\
\hline Feeder & & & $<0.0001$ \\
\hline 1 & 8.51 & 1.43 & $<0.0001$ \\
\hline 2 & 6.70 & 1.46 & $<0.0001$ \\
\hline 3 & -3.13 & 1.46 & 0.03 \\
\hline 4 & -1.23 & 1.45 & 0.40 \\
\hline 5 & 5.94 & 2.19 & 0.007 \\
\hline 6 & 13.70 & 1.74 & $<0.0001$ \\
\hline 7 & -0.75 & 1.45 & 0.61 \\
\hline 8 & 0 & - & - \\
\hline Year born & & & $<0.0001$ \\
\hline 2015 & 62.89 & 28.32 & 0.03 \\
\hline 2016 & 22.18 & 4.71 & $<0.0001$ \\
\hline 2017 & 13.57 & 4.56 & 0.003 \\
\hline 2018 & 11.11 & 4.48 & 0.01 \\
\hline 2019 & 0 & - & - \\
\hline Season born in & & & $<0.0001$ \\
\hline Winter & 1.53 & 1.15 & 0.19 \\
\hline Spring & 11.01 & 1.19 & $<0.0001$ \\
\hline Summer & 3.97 & 1.07 & 0.0002 \\
\hline Fall & 0 & - & - \\
\hline Respiratory incidence & & & 0.01 \\
\hline 0 & 4.22 & 1.83 & 0.02 \\
\hline 1 & 2.26 & 1.83 & 0.22 \\
\hline 2 & 1.34 & 1.99 & 0.50 \\
\hline 3 & 0 & - & - \\
\hline Scours incidence & & & 0.02 \\
\hline 0 & -25.83 & 12.51 & 0.04 \\
\hline 1 & -21.66 & 12.67 & 0.09 \\
\hline 2 & 0 & - & - \\
\hline Body size composite & 8.89 & 0.58 & $<.0001$ \\
\hline
\end{tabular}

in a 60 -d period. Milk consumption averages at varying day of age $(10,21,32,39,46,53,60 \mathrm{~d})$ are shown in Supplemental Figure 2 (https://doi.org/10.3168/ jds.2020-18560). Increasing total milk consumption increased $\mathrm{pBW}_{400}$ (quadratic $P<0.0001$; Figure 4; $\mathrm{R}^{2}$ $=0.16$ ). Higher birth weights resulted in heavier heifers at $400 \mathrm{~d}$ of age (Figure $5 ; \mathrm{R}^{2}=0.13$ ). Average birth weight was $40.6 \pm 4.9 \mathrm{~kg}$ (mean $\pm \mathrm{SD})$ with a range from 22.7 to $59.4 \mathrm{~kg}$.

Health factors including STP, scours incidence, and respiratory disease during the first $60 \mathrm{~d}$ of life were included in the model. After the data-tidying process explained prior in the materials and methods, the average STP value was $6.68 \pm 0.63 \mathrm{~g} / \mathrm{dL}($ mean $\pm \mathrm{SD})$

Table 5. Parameter estimates of significant factors used to predict BW at $400 \mathrm{~d}$ after not significant variables were removed from the model; this model removes the random effects of year, season, and feeder

\begin{tabular}{lccc}
\hline Variable & Estimate & SE & $P$-value \\
\hline Intercept & 193.41 & 19.72 & $<0.0001$ \\
Milk consumption & 0.55 & 0.06 & $<0.0001$ \\
Milk consumption $\times$ milk consumption & -0.0004 & 0.00006 & $<0.0001$ \\
Birth weight & 1.66 & 0.09 & $<0.0001$ \\
Respiratory incidence & & & $<0.0001$ \\
0 & 6.18 & 1.86 & 0.0009 \\
1 & 3.42 & 1.88 & 0.07 \\
2 & 1.94 & 2.04 & 0.34 \\
3 & 0 & - & 0.008 \\
Scours incidence & & 12.83 & 0.06 \\
0 & -24.03 & 13.00 & 0.15 \\
1 & -18.61 & - & - \\
2 & 0 & 0.60 & $<0.0001$ \\
Body size composite & 8.53 & & \\
\hline
\end{tabular}


and the values ranged from 4.6 to $9.2 \mathrm{~g} / \mathrm{dL}$ after. Effects of STP were significant on BW up to $100 \mathrm{~d}$ of age, and become not significant for time points beyond 100 d. Antibiotic treatment rate for scours did not significantly influence BW up to 365 d of age. At $400 \mathrm{~d}$, the variable became significant $(P<0.05)$, and calves diagnosed with scours had significantly higher BW at $400 \mathrm{~d}$. Respiratory disease also had a significant effect $(P<0.05)$ on predicted BW of heifers up to $400 \mathrm{~d}$. The association between different respiratory incidence rates and predicted BW of heifers is shown in Figure 6. For the first $200 \mathrm{~d}$, effect of each respiratory category was significantly different from one another (all $P<$ 0.05 ). At $300 \mathrm{~d}$ of age, respiratory disease category 2 and 3 were not significantly different from one another $(P=0.07)$, but were different from categories 0 and 1 $(P<0.05)$. At $400 \mathrm{~d}$, the $\mathrm{pBW}_{400}$ for animals without respiratory disease was significantly higher $(-1.95 \mathrm{~kg}$ for category $1,-2.9 \mathrm{~kg}$ for category 2 , and $-4.2 \mathrm{~kg}$ for category 3, compared with animals not diagnosed with respiratory disease between 1 and $60 \mathrm{~d}$ of age; $P$ $<0.05)$. As heifers age, preweaning respiratory disease had less of an effect on heifer predicted BW.
Genetic body size composite score was divided into quartiles and compared with $\mathrm{pBW}_{400}$ (Table 6). The average body size composite score for quartiles 1 through 4 were $-0.77,-0.12,0.31$, and 0.95 . Each quartile was significantly different from the other $(P<0.001)$, and the $\mathrm{pBW}_{400}$ for each quartile was $406.6,415.4,421.7$, and $428.1 \mathrm{~kg}$. There was a $21.6-\mathrm{kg}$ difference in predicted BW when comparing the top and bottom $25 \%$ of heifers.

\section{DISCUSSION}

Milk consumption, birth weight, feeder, year born, season born, respiratory incidence, scours incidences, and body size composite were all significant variables that affected predicted BW of dairy heifers. The milk consumption had a significant linear and quadratic effect on BW, indicating that each additional liter of milk did not increase predicted BW as much as the previous liter of milk. The quadratic effect may not be seen in conventional diets because of the set amount of milk fed to animals and little variation in intake of calves. By feeding intensified diets through an automatic calf

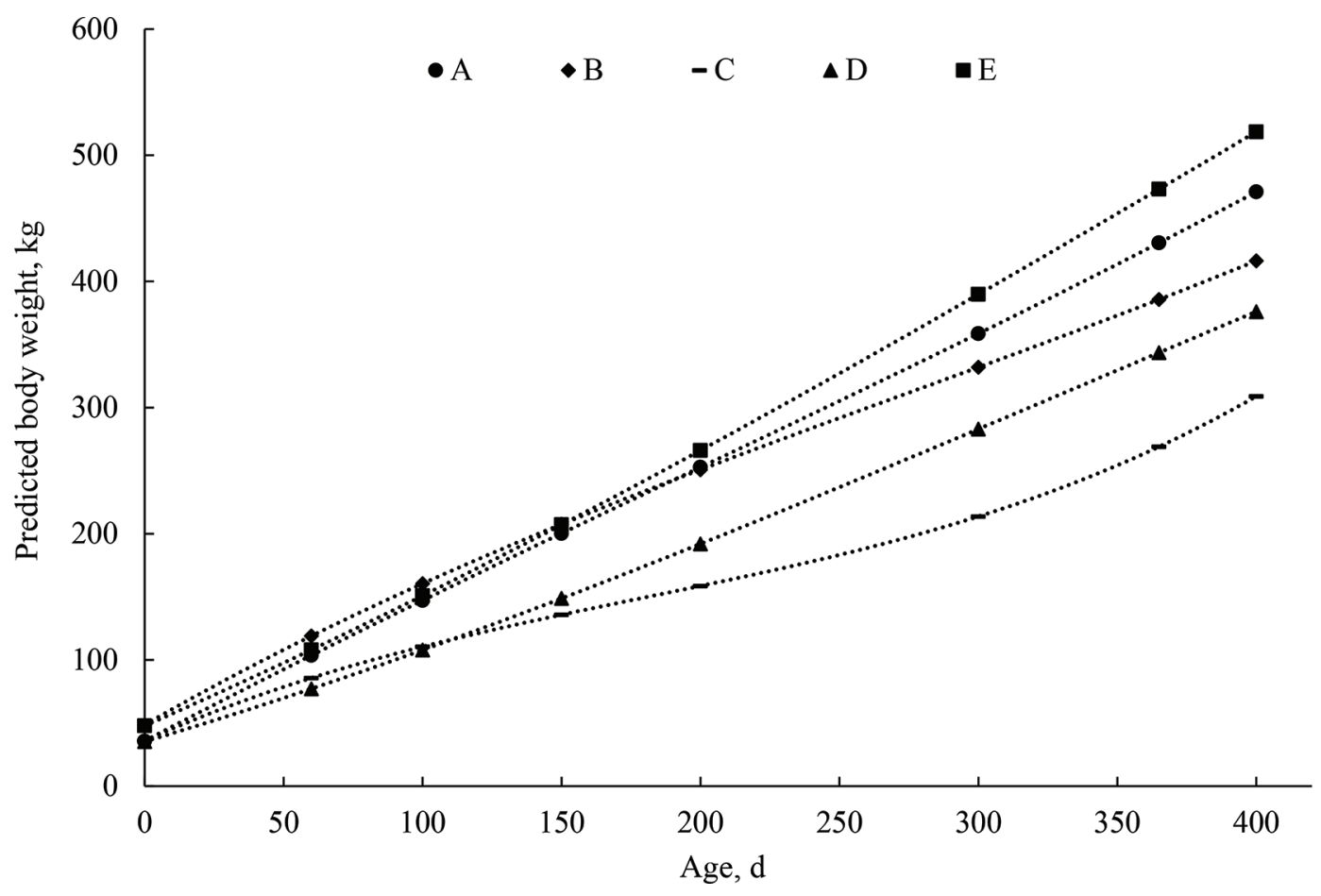

Figure 2. Comparison between predicted BW $(\mathrm{kg})$ of individual animals over time (d). Body weight was predicted using a third-order orthogonal polynomial. $\mathrm{A}=607 \mathrm{~L}$ intake of milk (whole pasteurized nonsalable milk with a $30 \%$ protein and $5 \%$ fat enhancer added at $20 \mathrm{~g} / \mathrm{L}$ milk), born in the summer 2017, no incidence of pneumonia, 1.18 genetic body size composite score, $48.08 \mathrm{~kg}$ at birth, and $6 \mathrm{~g} / \mathrm{dL}$ serum total protein. $\mathrm{B}=562.6 \mathrm{~L}$ intake of milk, born in the fall 2017 , no incidence of pneumonia, 0.83 genetic body size composite score, $40.82 \mathrm{~kg}$ at birth, $6.2 \mathrm{~g} / \mathrm{dL}$ serum total protein. $\mathrm{C}=429.6 \mathrm{~L}$ intake of milk, born in winter 2018,1 pneumonia treatment, 0.48 genetic body size composite score, $38.41 \mathrm{~kg}$ at birth, $6.4 \mathrm{~g} / \mathrm{dL}$ serum total protein. $\mathrm{D}=370.4 \mathrm{~L}$ intake of milk, born summer 2018,1 pneumonia treatment, -0.41 genetic body size composite score, $36.74 \mathrm{~kg}$ at birth, $6.8 \mathrm{~g} / \mathrm{dL}$ serum total protein. $\mathrm{E}=633.2 \mathrm{~L}$ intake of milk, born spring 2017, no incidence of pneumonia, -0.11 genetic body size composite score, $35.83 \mathrm{~kg}$ at birth, $6 \mathrm{~g} / \mathrm{dL}$ serum total protein. 
feeder, there was variation in milk consumption between calves, and we were able to observe the effect of milk consumption on BW. In our study, when comparing a single variable, milk consumption accounted for $16 \%$ of the variation in BW at $400 \mathrm{~d}$. Feeding of intensified diets during the preweaning phase has affected growth later in life in other studies as well. Davis Rincker et al. (2011) reported heifers on an intensified diet reached the breeding target weight of $397 \mathrm{~kg}$ sooner than those on a conventional diet. However, others find no advantage of intensified feeding on BW after weaning (Morrison et al., 2009; Kiezebrink et al., 2015; Dennis et al., 2018). Most research looking into the effect of milk feeding strategies on growth of calves offer a specified amount of milk in their treatments. In automatic calf feeders, calves have the option to choose the amount of milk they consume; therefore, the milk consumption factor could produce a different result on farms that individually house calves and only offer a set amount of milk or milk replacer.

Heifers with higher birth weight had higher $\mathrm{pBW}_{400}$. Greenwood et al. (2006) found that finished beef cattle (Piedmontese or Wagyu crossed) with lower birth weights weighed $56 \mathrm{~kg}$ less at 30 mo old than higher birth weight cattle. In contrast, Donovan et al. (1998) found that birth weight only affected weight gain up to 6 mo of age. Even though higher birth weight results in heavier animals at $400 \mathrm{~d}$, increases in birth weight can also lead to increases in dystocia rate of cows. Johanson and Berger (2003) revealed that dystocia increased $13 \%$ per 1-kg increase in birth weight. Calf birth weight can affect dam production. Rahbar et al. (2016) observed that cows with lower birth weight calves $(20-25 \mathrm{~kg})$ had lower 305-d milk production than cows with 40- to $45-\mathrm{kg}$ birth weight calves. Therefore, it is important to consider calf birth weight when understanding calf BW.

Respiratory disease has a significant effect on heifer BW through $400 \mathrm{~d}$. If a calf was treated for respiratory disease once, there was a $0.71-\mathrm{kg}$ reduction in predicted $\mathrm{BW}$ at $60 \mathrm{~d}$ of age and $\sim 2-\mathrm{kg}$ difference at $400 \mathrm{~d}$. At $60 \mathrm{~d}$, each respiratory disease category was significantly different from the other. Over time and at $400 \mathrm{~d}$, calves treated once, twice, or 3 or more times were not statistically different from one another, but if calves were not treated, they were statistically different from calves treated for respiratory disease. Other research reported that preweaning respiratory disease negatively affects BW (van der Fels-Klerx et al., 2001; Stanton et al., 2012). Our objective was to determine which factors in early life affect future BW; therefore, we only considered preweaning respiratory disease, but respiratory disease postweaning would likely have an effect on BW after the 60-d time point (Adams and Buczinski, 2016). Additionally, if calf health scoring charts (McGuirk, 2008) or thoracic ultrasonography (Adams and Buczinski, 2016) were used to identify calves with

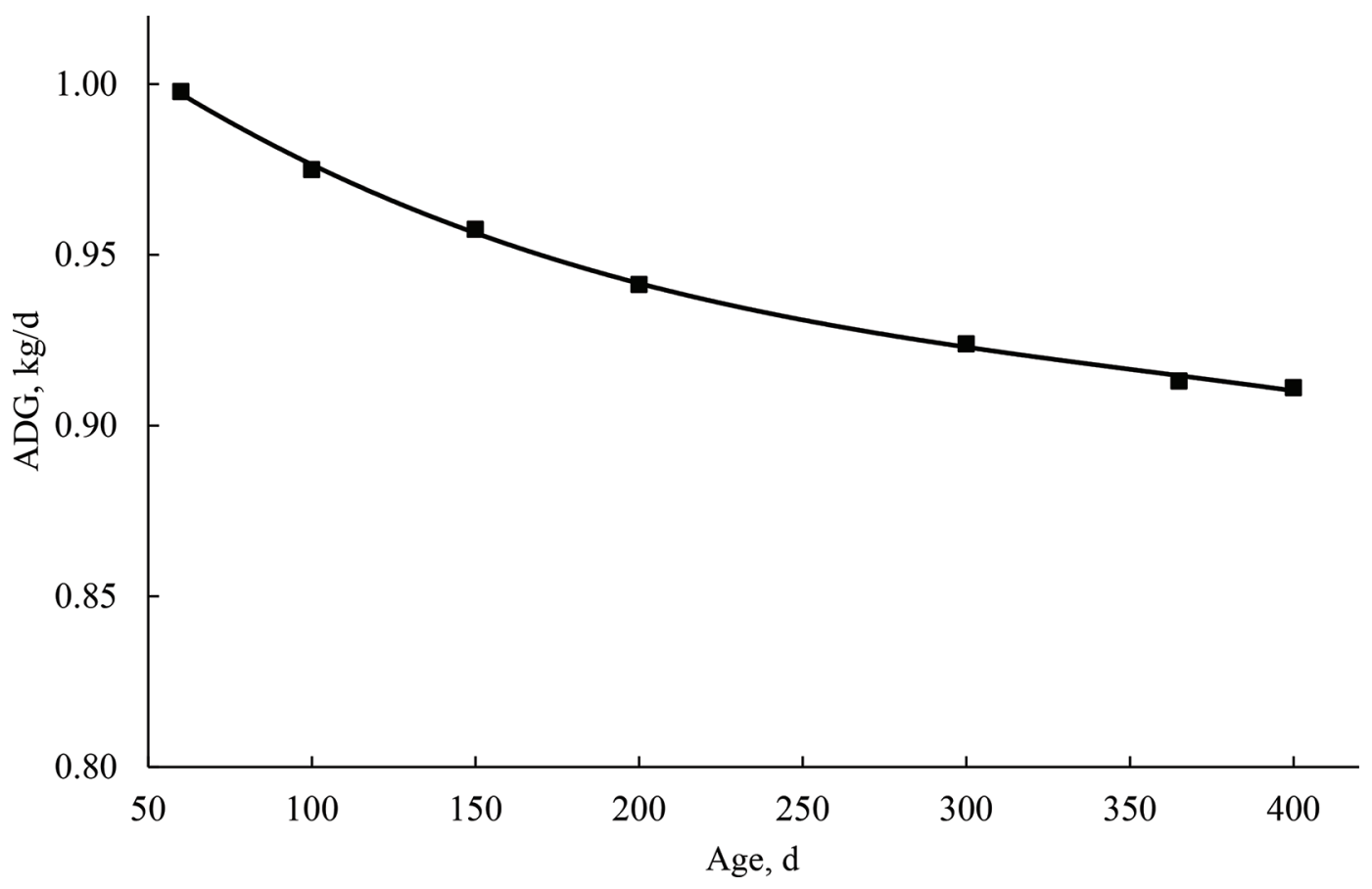

Figure 3. Average daily gain of heifers over time. $\mathrm{ADG}=-2 \mathrm{E}^{-09} \mathrm{x}^{3}+2 \mathrm{E}^{-06} \mathrm{x}^{2}-0.0008 \mathrm{x}+1.0375 ; \mathrm{x}=$ age at measurement and $\mathrm{R}^{2}=0.9987$. 
respiratory disease rather than treatment records, the results may have had a larger effect on predicted BW due to increased accuracy of disease detection.

Scours is the most common disease diagnosed in preweaned dairy calves, with $16 \%$ of preweaned calves treated for digestive problems (USDA, 2018). Preweaning scours incidence was never significant in the model until $400 \mathrm{~d}$ of age, at which point calves with scours had higher predicted $\mathrm{BW}$ in comparison to calves without scours. We believe that this was due to the relatively low number of incidences on this specific farm recorded in their records. Donovan et al. (1998) predicted a 9.1$\mathrm{kg}$ reduction in 180-d weight gain when calves were treated an average of $3.76 \mathrm{~d}$ for scours, but scours incidence did not affect weight gain after 6 mo. However, Curtis et al., (2018) reported no difference in growth with varying scours incidences. From October 1, 2015, to January 1, 2019, there were only 237 animals treated for scours with antibiotics in our analysis. Other scours treatments on this farm included oral electrolytes and Bismuth Subsalicylate, which were not recorded in the farm management software. Therefore, only animals treated with antibiotics for scours were recorded and included in the analysis. If all incidences of scours were recorded, scours incidences might have had a different outcome in the model. Another possible explanation for the unexpected scours results is that the increase in milk consumed could have caused looser stool, leading to treatment for scours even if the calf was not clinically ill.

Introducing genetic variables improved reliability of the overall predictive equation; body size composite score accounted for $5.7 \%$ of BW differences in heifers at $400 \mathrm{~d}$. The body size composite score measurement included in this analysis measured the difference in animal's stature, strength, body depth, and width of rump (Zoetis). A higher body size composite score indicated a larger animal. It was estimated that a 1-point increase in body size composite showed an 18.2-kg increase in mature BW. When body size composite was divided into quartiles, there was a $21.5-\mathrm{kg}$ difference in BW between the top and bottom $25 \%$ of animals, which had an average 1.72 increase in body size composite score.

Year effect was highly significant in the model up to $400 \mathrm{~d}$ with a decrease of 40.5, 8.6, 2.6, and $11.1 \mathrm{~kg}$ from 2015 to 2019. Other research has found year to also be significant when measuring BW over time (Donovan et al., 1998; Cue et al., 2012). Based on evidence seen by Dietrich (2015) looking at standard plate and coliform count in autofeeders pre- and postcleaning, bacteria buildup in the autofeeders as they age could explain some of the differences seen among years. We speculate that bacterial load in the autofeeders increased over time, resulting in reduced animal performance.

Eight automatic calf feeders on a single farm is relatively uncommon. Research done on 10 commercial

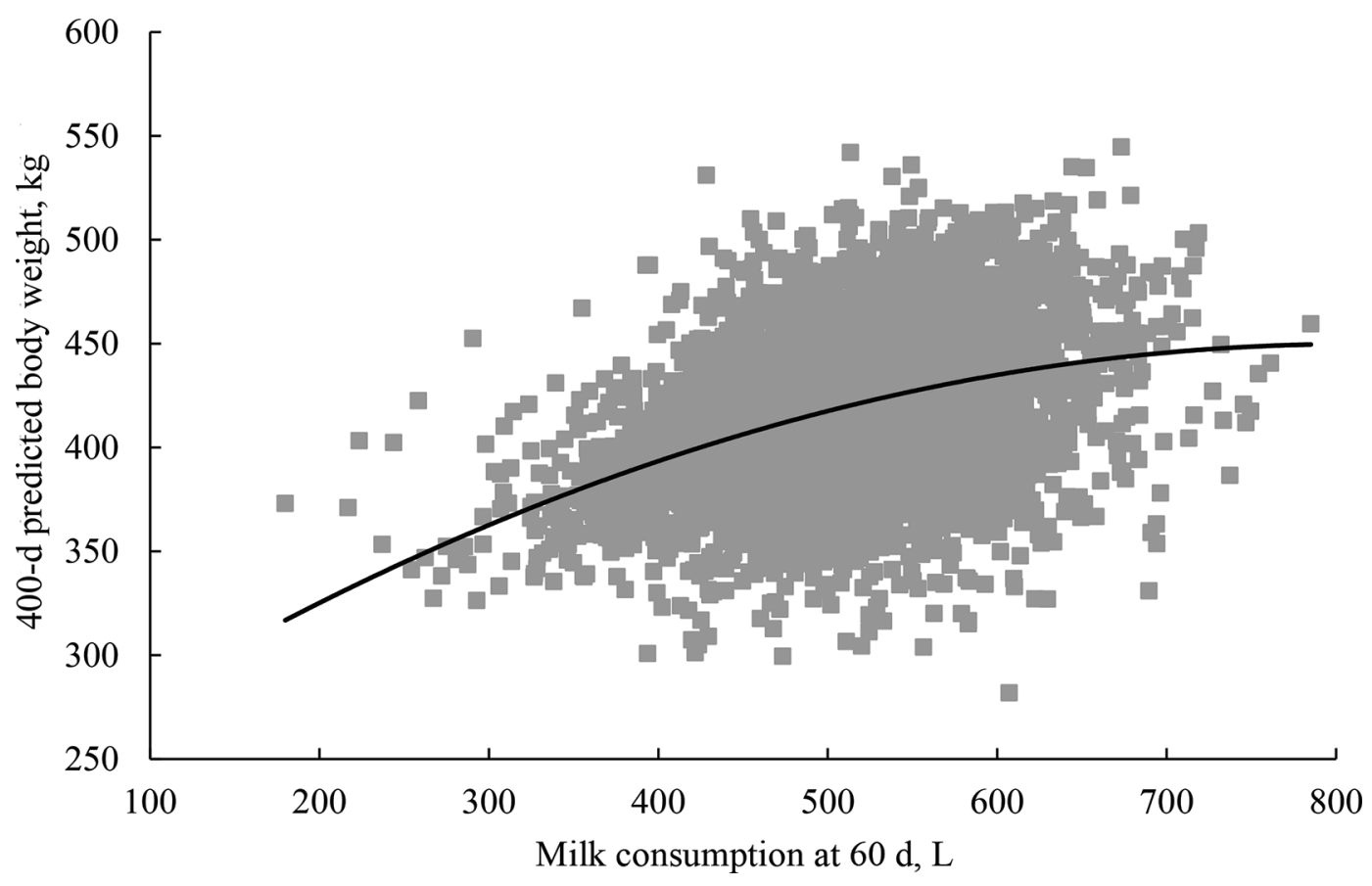

Figure 4. The effect 60-d milk consumption has on the predicted BW of animals at $400 \mathrm{~d}$ (p400BW). The equation for milk consumption: $\mathrm{p} 400 \mathrm{BW}=-0.0003 \mathrm{x}^{2}+0.5417 \mathrm{x}+230.22 ; \mathrm{x}=$ milk consumption $(\mathrm{L})$ and $\mathrm{R}^{2}=0.16$ 


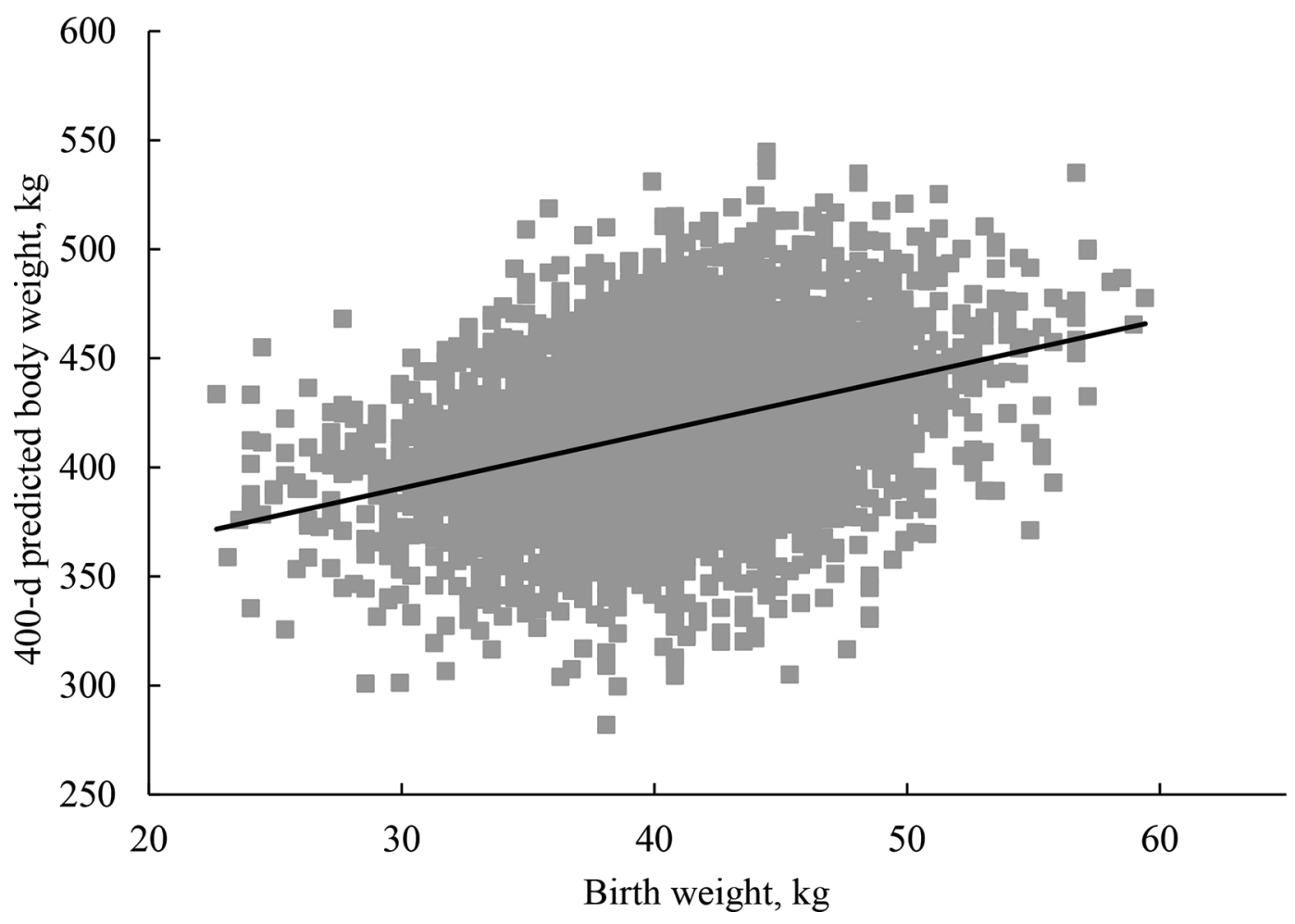

Figure 5. The effect of birth weight on the predicted BW of animals at $400 \mathrm{~d}$ (p400BW). The equation for birthweight: p400BW $=2.5626 \mathrm{x}$ $+313.58 ; \mathrm{x}=$ birth weight $(\mathrm{kg})$ and $\mathrm{R}^{2}=0.13$.

dairy farms with automated calf feeders averaged 1.4 feeders per farm (Dietrich, 2015); therefore, not much is known about the effect different feeders on the same farm have on growth. Some variation could be due to factors that we are not controlling for, including year in which feeders were installed $(1,2,3$, and $4=2015$; 7 and $8=2016$; and 5 and $6=2017)$, barn location, or unforeseen weather events. Because not all autofeeders were installed at the same time or in the same location, this may explain some of the variation seen in $\mathrm{BW}$ of animals raised in different feeders. Regardless, feeder had a significant effect on heifer BW at $400 \mathrm{~d}$.

Similar to what others have reported, season affects animal BW and performance (Donovan et al., 1998; van der Fels-Klerx et al., 2001; Handcock et al., 2019). Results of seasonal effect may vary due to the months used to define a season. Our study defined winter as January to March; while van der Fels-Klerx et al. (2001) defined winter as November through January. Seasonal effect was also considered when examining different growth intervals such as season of birth date (as in our study), season at weaning, or season at breeding. Because studies define seasons differently and measure seasonal effect at different growth intervals, it often becomes difficult to compare seasonal effect across research findings. For example, in the current study, calves born in winter were the heaviest up to $300 \mathrm{~d}$, but those born in the spring had the heaviest BW at 400 d. Chester-Jones et al. (2017) reported that calves born in the fall and winter had the highest BW at $8 \mathrm{wk}$ old. Although they did not measure growth past $8 \mathrm{wk}$, this study found that calves born in the summer had higher 305-d milk yield (Chester-Jones et al., 2017).

Of those variables, STP and number of days on feeder were not significant at $400 \mathrm{~d}$ and removed from the model. Effect of STP was significant up to $100 \mathrm{~d}$ of age on heifer BW. The average STP value on this farm was $6.67 \mathrm{~g} / \mathrm{dL}$. Weaver et al. (2000) and Renaud et al. (2018) found that calves with $\geq 5.2 \mathrm{~g} / \mathrm{dL}$ or $\geq 5.1 \mathrm{~g} / \mathrm{dL}$ STP have successful passive transfer of immunity. The average on the commercial farm exceeded this target number, and $95 \%$ of calves had a STP value $\geq 6 \mathrm{~g} / \mathrm{dL}$; therefore, this could be 1 reason STP was not significant in the final 400-d model.

The average number of days animals consumed milk in the automated calf feeder was $60 \pm 4.6$ (mean \pm $\mathrm{SD})$. This variable was significant in the model to at least $300 \mathrm{~d}$ of age; however, this variable became insignificant at time points 365 and $400 \mathrm{~d}$ of age. This is reasonable because the more time calves spend on the feeder, the more they consume, and consequently (because milk consumption affects BW) the higher 


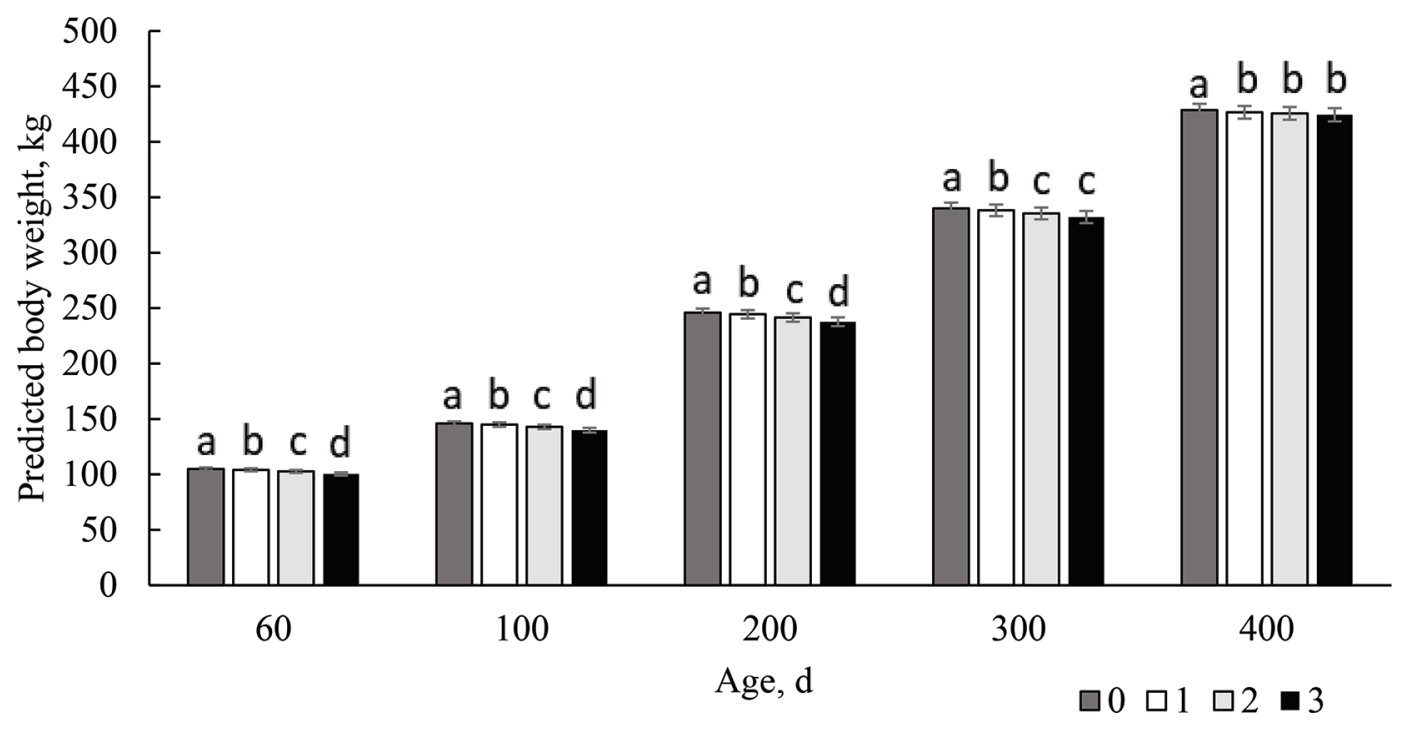

Figure 6 . The effect of respiratory disease on predicted BW over time $(60,100,200,300,400 \mathrm{~d}) .0=$ no treatment, $1=1$ treatment, $2=2$ treatments, $3=3$ or more treatments. Means with different letters $(\mathrm{a}-\mathrm{d})$ are significantly different $(P<0.05)$.

their predicted BW will be (de Passillé et al., 2011). In contrast to this finding, the results from time points up to $300 \mathrm{~d}$ of age indicate that the longer the calves were on the automated calf feeder, the lower their predicted BW were. This finding is not surprising because calves that had higher days on the feeder were held back by the farm due to lower performance in comparison to pen mates.

Of the significant variables in the model, year born, season born, and the feeder the calf was in were not variables that can be measured and improved on-farm. To generate an equation to better monitor measurable variables that affect heifer performance, all 3 variables were removed from the model. Cue et al. (2012) removed herd, year, and month because they wanted to generate a predictive model. Excluding significant variables introduces error, but including them will diminish the usefulness of the model when implementing it on-farm. If used in the predictive model, future predictions become unimportant because the effects of a different year born, season born, or feeder are not known. Therefore, the final predictive model on this commercial dairy farm included milk consumption and the quadratic effect, birth weight, respiratory incidence, and body size composite score $\left(\mathrm{R}^{2}=0.27\right)$.

There was a $263-\mathrm{kg}$ difference in predicted BW at $400 \mathrm{~d}$ from the lightest to the heaviest heifer present in the data set. Based on the results found in the study, variables collected during the first $60 \mathrm{~d}$ of life were able to account for over $30 \%$ of the difference in BW up to $400 \mathrm{~d}$ of age. The next steps will be to understand how early life affects other production variables later in life.

Some limitations to this study include the inability to quantify starter intake for calves. With starter intake, we could accurately understand how all nutrients during the preweaning period affected BW. Variable respiratory treatment rates are seen on-farm, and thus using a more standardized scale such as thoracic ultrasonography to identify damage from respiratory disease could help us better understand the effect this variable has on growth (Buczinski et al., 2015; Cramer and Ollivett, 2019). Additionally, data generated from this study did not allow for an accurate analysis of the effect of scours on predicted BW due to the inability to account for all types of treatments. Because the farm only recorded antibiotic treatments, our analysis could

Table 6. The effect of body size composite score on predicted BW of animals at $400 \mathrm{~d}$; body size composite score was divided into quartiles with the average and range presented for each quartile

\begin{tabular}{lcccc}
\hline Quartile & $\begin{array}{c}\text { Average body } \\
\text { size composite }\end{array}$ & $\begin{array}{c}\text { Range body } \\
\text { size composite }\end{array}$ & $\begin{array}{c}\text { Predicted } \\
\text { BW mean }\end{array}$ & SEM \\
\hline 1 & -0.77 & -2.62 to -0.36 & 406.6 & 0.90 \\
2 & -0.12 & -0.36 to 0.09 & 415.4 & 0.90 \\
3 & 0.31 & 0.09 to 0.54 & 421.7 & 0.90 \\
4 & 0.95 & 0.54 to 3.05 & 428.1 & 0.90 \\
\hline
\end{tabular}


not consider animals treated with nonantibiotic treatments. In the future, our analysis would ideally include heifer hip height and hip width to most accurately identify growth of heifers because the current analysis only accounted for the difference in BW. Future research needs to validate this predictive model and be able to adjust the equation for each farm.

\section{CONCLUSIONS}

Early-life variables collected during the preweaning phase can influence over $25 \%$ of the variation in heifer BW at $400 \mathrm{~d}$ on a single commercial dairy. Combining phenotypic and genotypic traits allowed us to generate a predictive model that a farm can use to aid in making management decisions. It is important to note that there are influential variables that are out of a farm's control, and this predictive equation will only match findings found on this single dairy farm. Future research will work to understand how to best implement this model based on an individual farm's data collection.

\section{ACKNOWLEDGMENTS}

The authors thank Homestead Dairy, LLC (Plymouth, IN), and especially Brian and Jill Houin for inviting us on their farm and for allowing our research group for to use the farm records. Their help and farm records access has been invaluable in understanding heifer BW. The authors acknowledge the generous support from an internal competitive grant at Purdue University (AgSEED \#00076579). The authors have not stated any conflicts of interest.

\section{REFERENCES}

Adams, E. A., and S. Buczinski. 2016. Short communication: Ultrasonographic assessment of lung consolidation postweaning and survival to the first lactation in dairy heifers. J. Dairy Sci. 99:14651470. https://doi.org/10.3168/jds.2015-10260.

Akins, M. S. and M. A. Hagedorn. 2015. The cost of raising dairy replacements - 2015 updates. Heifer Management Blueprints. Accessed Oct. 2020. https://fyi.extension.wisc.edu/dairy/files/2015/ 10/2015-Cost-of-Raising-Replacements-Factsheet-Final.pdf.

Buczinski, S., T. L. Ollivett, and N. Dendukuri. 2015. Bayesian estimation of the accuracy of the calf respiratory scoring chart and ultrasonography for the diagnosis of bovine respiratory disease in pre-weaned dairy calves. Prev. Vet. Med. 119:227-231. https://doi .org/10.1016/j.prevetmed.2015.02.018.

Byrne, C. J., S. Fair, A. M. English, M. Cirot, C. Staub, P. Lonergan, and D. A. Kenny. 2018. Plane of nutrition before and after 6 months of age in Holstein-Friesian bulls: I. Effects on performance, body composition, age at puberty, and postpubertal semen production. J. Dairy Sci. 101:3447-3459.

Chester-Jones, H., B. J. Heins, D. Ziegler, D. Schimek, S. Schuling, B. Ziegler, M. B. de Ondarza, C. J. Sniffen, and N. Broadwater. 2017. Relationships between early-life growth, intake, and birth season with first-lactation performance of Holstein dairy cows. J. Dairy Sci. 100:3697-3704. https://doi.org/10.3168/jds.2016-12229.

Costa, J. H., R. R. Daros, M. A. G. von Keyserlingk, and D. M. Weary. 2014. Complex social housing reduces food neophobia in dairy calves. J. Dairy Sci. 97:7804-7810.

Cramer, M. C., and T. L. Ollivett. 2019. Growth of preweaned, grouphoused dairy calves diagnosed with respiratory disease using clinical respiratory scoring and thoracic ultrasound-A cohort study. J. Dairy Sci. 102:4322-4331. https://doi.org/10.3168/jds.2018-15420.

Cue, R. I., D. Pietersma, D. Lefebvre, R. Lacroix, K. Wade, D. Pellerin. A. M. de Passillé, and J. Rushen. 2012. Growth modeling of dairy heifers in Québec based on random regression. Can. J. Anim. Sci. 92:33-47. https://doi.org/10.4141/cjas2011-083.

Curtis, G., C. Mc Gregor Argo, D. Jones, and D. Grove-White. 2018. The impact of early life nutrition and housing on growth and reproduction in dairy cattle. PLoS One 13:e0191687. https://doi .org/10.1371/journal.pone.0191687.

Davis Rincker, L. E., M. J. VandeHaar, C. A. Wolf, J. S. Liesman, L. T. Chapin, and M. S. Weber Nielsen. 2011. Effect of intensified feeding of heifer calves on growth, pubertal age, calving age, milk yield, and economics. J. Dairy Sci. 94:3554-3567. https://doi.org/ 10.3168/jds.2010-3923.

de Passillé, A. M., T. F. Borderas, and J. Rushen. 2011. Weaning age of calves fed a high milk allowance by automated feeders: Effects on feed, water, and energy intake, behavioral signs of hunger, and weight gains. J. Dairy Sci. 94:1401-1408. https://doi.org/10.3168/ jds.2010-3441.

Dennis, T. S., F. X. Suarez-Mena, T. M. Hill, J. D. Quigley, R. L. Schlotterbeck, and L. Hulbert. 2018. Effect of milk replacer feeding rate, age at weaning, and method of reducing milk replacer to weaning on digestion, performance, rumination, and activity in dairy calves to 4 months of age. J. Dairy Sci. 101:268-278. https:/ /doi.org/10.3168/jds.2017-13692.

Dietrich, A. M. 2015. Management, sanitation, and accuracy of automated calf feeders. MS thesis. Department of Dairy Science. Virginia Polytechnic Institute. Blacksburg, VA.

Donovan, G. A., I. R. Dohoo, D. M. Montgomery, and F. L. Bennett. 1998. Calf and disease factors affecting growth in female Holstein calves in Florida, USA. Prev. Vet. Med. 33:1-10. https://doi.org/ 10.1016/S0167-5877(97)00059-7.

Drackley, J. K. 2008. Calf nutrition from birth to breeding. Vet. Clin. North Am. Food Anim. Pract. 24:55-86. https://doi.org/10.1016/ j.cvfa.2008.01.001.

Dunn, T. R., T. L. Ollivett, D. L. Renaud, K. E. Leslie, S. J. LeBlanc, T. F. Duffield, and D. F. Kelton. 2018. The effect of lung consolidation, as determined by ultrasonography, on first-lactation milk production in Holstein dairy calves. J. Dairy Sci. 101:5404-5410. https://doi.org/10.3168/jds.2017-13870.

Elsohaby, I., J. T. Mcclure, and G. P. Keefe. 2015. Evaluation of digital and optical refractometers for assessing failure of transfer of passive immunity in dairy calves. J. Vet. Intern. Med. 29:721-726. https://doi.org/10.1111/jvim.12560.

Ettema, J. F., and J. E. P. Santos. 2004. Impact of age at calving on lactation, reproduction, health, and income in first-parity Holsteins on commercial farms. J. Dairy Sci. 87:2730-2742. https:// doi.org/10.3168/jds.S0022-0302(04)73400-1.

Greenwood, P. L., L. M. Cafe, H. Hearnshaw, D. W. Hennessy, J. M. Thompson, and S. G. Morris. 2006. Long-term consequences of birth weight and growth to weaning on carcass, yield and beef quality characteristics of Piedmontese- and Wagyu-sired cattle. Aust. J. Exp. Agric. 46:257-269. https://doi.org/10.1071/EA05240.

Handcock, R. C., N. Lopez-Villalobos, L. R. McNaughton, P. J. Back, G. R. Edwards, and R. E. Hickson. 2019. Live weight and growth of Holstein-Friesian, Jersey and crossbred dairy heifers in New Zealand. N. Z. J. Agric. Res. 62:173-183. https://doi.org/10.1080/ 00288233.2018.1465984.

Heins, B. D., D. V. Nydam, A. R. Woolums, R. D. Berghaus, and M. W. Overton. 2014. Comparative efficacy of Enrofloxacin and Tulathromycin for treatment of preweaning respiratory disease in dairy heifers. J. Dairy Sci. 97:372-382. https://doi.org/10.3168/ jds.2013-6696. 
James, R. E., and M. C. Scott. 2005. On Farm Pasteurizer Management for Waste Milk Quality Control. Accessed Oct., 2020. https: //www.vtdairy.dasc.vt.edu/content/dam/vtdairy_dasc_vt_edu/ documents/replacements/replace-on-farm-mgmt-waste-milk-qc .pdf

Jasper, J., and D. M. Weary. 2002. Effects of ad libitum milk intake on dairy calves. J. Dairy Sci. 85:3054-3058. https://doi.org/10.3168/ jds.S0022-0302(02)74391-9.

Johanson, J. M., and P. J. Berger. 2003. Birth weight as a predictor of calving ease and perinatal mortality in Holstein cattle. J. Dairy Sci. 86:3745-3755. https://doi.org/10.3168/jds.S0022-0302(03)73981-2 .Khan, M. A., H. J. Lee, W. S. Lee, H. S. Kim, S. B. Kim, K. S. Ki, J. K. Ha, H. G. Lee, and Y. J. Choi. 2007. Pre- and postweaning performance of Holstein female calves fed milk through step-down and conventional methods. J. Dairy Sci. 90:876-885. https://doi .org/10.3168/jds.S0022-0302(07)71571-0.

Khan, M. A., D. M. Weary, and M. A. G. von Keyserlingk. 2011. Invited review: Effects of milk ration on solid feed intake, weaning, and performance in dairy heifers. J. Dairy Sci. 94:1071-1081.

Kiezebrink, D. J., A. M. Edwards, T. C. Wright, J. P. Cant, and V. R. Osborne. 2015. Effect of enhanced whole-milk feeding in calves on subsequent first-lactation performance. J. Dairy Sci. 98:349-356. https://doi.org/10.3168/jds.2014-7959.

Kirkpatrick, M., D. Lofsvold, and M. Bulmer. 1990. Analysis of the inheritance, selection and evolution of growth trajectories. Genetics 124:979-993.

McGuirk, S. M. 2008. Disease management of dairy calves and heifers. Vet. Clin. North Am. Food Anim. Pract. 24:139-153.

Miller-Cushon, E. K., R. Bergeron, K. E. Leslie, and T. J. DeVries. 2013. Effect of milk feeding level on development of feeding behavior in dairy calves. J. Dairy Sci. 96:551-564. https://doi.org/10 $.3168 /$ jds.2012-5937.

Morrison, S. J., H. C. F. Wicks, R. J. Fallon, J. Twigge, L. E. R. Dawson, A. R. G. Wylie, and A. F. Carson. 2009. Effects of feeding level and protein content of milk replacer on the performance of dairy herd replacements. Animal 3:1570-1579. https://doi.org/10 $.1017 /$ S1751731109990437.

Pietersma, D., R. Lacroix, D. Lefebvre, R. Cue, and K. M. Wade. 2006. Trends in growth and age at first calving for Holstein and Ayrshire heifers in Quebec. Can. J. Anim. Sci. 86:325-336.

Quigley, J. D., T. A. Wolfe, and T. H. Elsasser. 2006. Effects of additional milk replacer feeding on calf health, growth, and selected blood metabolites in calves. J. Dairy Sci. 89:207-216. https://doi .org/10.3168/jds.S0022-0302(06)72085-9.

Raeth-Knight, M., H. Chester-Jones, S. Hayes, J. Linn, R. Larson, D. Ziegler, B. Ziegler, and N. Broadwater. 2009. impact of conventional or intensive milk replacer programs on Holstein heifer performance through six months of age and during first lactation. J. Dairy Sci. 92:799-809. https://doi.org/10.3168/jds.2008-1470.

Rahbar, R., R. Abdullahpour, and A. S. Sefidmazgi. 2016. Effect of calf birth weight on milk production of Holstein dairy cattle in desert climate. J. Anim. Behav. Biom. 4:65-70. https://doi.org/10 .14269/2318-1265/jabb.v4n3p65-70.
Renaud, D. L., T. F. Duffield, S. J. LeBlanc, and D. F. Kelton. 2018. Short communication: Validation of methods for practically evaluating failed passive transfer of immunity in calves arriving at a veal facility. J. Dairy Sci. 101:9516-9520. https://doi.org/10.3168/ jds.2018-14723.

Rosenberger, K., J. H. C. Costa, H. W. Neave, M. A. G. von Keyserlingk, and D. M. Weary. 2017. The effect of milk allowance on behavior and weight gains in dairy calves. J. Dairy Sci. 102:504-512.

Rutten, C. J., A. G. J. Velthuis, W. Steeneveld, and H. Hogeveen. 2013. Invited review: Sensors to support health management on dairy farms. J. Dairy Sci. 96:1928-1952. https://doi.org/10.3168/ jds.2012-6107.

Soberon, F., E. Raffrenato, R. W. Everett, and M. E. Van Amburgh. 2012. Preweaning milk replacer intake and effects on long-term productivity of dairy calves. J. Dairy Sci. 95:783-793. https://doi .org/10.3168/jds.2011-4391.

Stanton, A. L., D. F. Kelton, S. J. LeBlanc, J. Wormuth, and K. E. Leslie. 2012. The Effect of respiratory disease and a preventative antibiotic treatment on growth, survival, age at first calving, and milk production of dairy heifers. J. Dairy Sci. 95:4950-4960. https: //doi.org/10.3168/jds.2011-5067.

Teixeira, A. G. V., J. A. A. McArt, and R. C. Bicalho. 2017. Thoracic ultrasound assessment of lung consolidation at weaning in Holstein dairy heifers: reproductive performance and survival. J. Dairy Sci. 100:2985-2991. https://doi.org/10.3168/jds.2016-12016.

Tozer, P. R., and A. J. Heinrichs. 2001. What affects the costs of raising replacement dairy heifers: A multiple-component analysis. J. Dairy Sci. 84:1836-1844. https://doi.org/10.3168/jds.S0022 -0302(01)74623-1.

Tyler, J. W., D. D. Hancock, S. M. Parish, D. E. Rea, T. E. Besser, S. G. Sanders, and L. K. Wilson. 1996. Evaluation of 3 assays for failure of passive transfer in calves. J. Vet. Intern. Med. 10:304-307. https://doi.org/10.1111/j.1939-1676.1996.tb02067.x.

USDA. 2018. Dairy 2014: Heifer calf health and management practices on U.S. dairy operations. USDA-APHIS-VS-CEAH, No 550.0110. Fort Collins, CO.

van der Fels-Klerx, H. J., J. T. Sorensen, A. W. Jalvingh, and R. B. M. Huirne. 2001. An economic model to calculate farm-specific losses due to bovine respiratory disease in dairy heifers. Prev. Vet. Med. 51:75-94. https://doi.org/10.1016/S0167-5877(01)00208-2.

von Keyserlingk, M. A. G., J. Rushen, A. M. B. de Passillé, and D. M. Weary. 2009. Invited review: The welfare of dairy cattle-Key concepts and the role of science. J. Dairy Sci. 92:4101-4111. https: //doi.org/10.3168/jds.2009-2326.

Weaver, D. M., J. W. Tyler, D. C. VanMetre, D. E. Hostetler, and G. M. Barrington. 2000. Passive transfer of colostral immunoglobulins in calves. J. Vet. Intern. Med. 14:569-577. https://doi.org/10 $.1111 /$ j.1939-1676.2000.tb02278.x.

Wilm, J., J. H. C. Costa, H. W. Neave, D. M. Weary, and M. A. G. von Keyserlingk. 2018. Technical note: Serum total protein and immunoglobulin G concentrations in neonatal dairy calves over the first 10 days of age. J. Dairy Sci. 101:6430-6436. https://doi.org/ $10.3168 /$ jds.2017-13553. 